\title{
Inhibitory effects and underlying mechanisms of Artemisia capillaris essential oil on melanogenesis in the B16F10 cell line
}

\author{
MIN JAE KIM ${ }^{1}$, ELSAYED A. MOHAMED ${ }^{1,2}$, DA SOM KIM ${ }^{1}$, MI-JIN PARK ${ }^{3}$, \\ BYOUNG-JUN AHN ${ }^{3}$, EUI-BAE JEUNG ${ }^{4}$ and BEUM-SOO AN ${ }^{1}$
}

\begin{abstract}
${ }^{1}$ Department of Biomaterials Science (BK21 FOUR Program), College of Natural Resources and
Life Science/Life and Industry Convergence Research Institute, Pusan National University, Miryang, Gyeongsangnam-do 50463, Republic of Korea; ${ }^{2}$ Department of Genetics, Assiut University, Assiut 71526, Egypt;

${ }^{3}$ Division of Forest Industrial Materials, Department of Forest Products and Industry, National Institute of Forest Science, Seoul 02455; ${ }^{4}$ Laboratory of Veterinary Biochemistry and Molecular Biology, College of Veterinary Medicine, Chungbuk National University, Cheongju, Chungbuk 28644, Republic of Korea
\end{abstract}

Received September 15, 2021; Accepted January 11, 2022

DOI: $10.3892 / \mathrm{mmr} .2022 .12629$

\begin{abstract}
The present study investigated the anti-melanogenic activity of 10 essential oils using the B16F10 cell model. Initially, a wide range of concentrations of these essential oils were screened in order to determine their toxicity levels. The assigned non-toxic concentrations of the tested essential oils were then used to evaluate their effects on melanogenesis. The effects of the essential oils with potent anti-melanogenic activity on cell proliferation, protection against $\mathrm{H}_{2} \mathrm{O}_{2}$-induced cell death and the expression of certain melanogenesis-related genes, including MITF, tyrosinase, tyrosinase related protein (TRP)-1 and TRP-2 were also evaluated. The results revealed that the essential oils extracted from Citrus unshiu, Juniperus chinensis L., Zanthoxylum piperitum and Artemisia capillaris (A. capillaris) inhibited melanogenesis. However, among these four extracts, only A. capillaris extract enhanced cell proliferation, exhibited anti- $\mathrm{H}_{2} \mathrm{O}_{2}$ activities and decreased the expression level of TRP-1. It was demonstrated that $A$. capillaris extract inhibited melanin synthesis via the downregulation of the TRP-1 translational level. These essential oil extracts, particularly that of A. capillaris, may thus be used as natural anti-melanogenic agents for therapeutic purposes and in the cosmetic industry for skin whitening
\end{abstract}

Correspondence to: Professor Beum-Soo An, Department of Biomaterials Science (BK21 FOUR Program), College of Natural Resources and Life Science/Life and Industry Convergence Research Institute, Pusan National University, 50 Cheonghak-ri, Samrangjin-eup, Miryang, Gyeongsangnam-do 50463, Republic of Korea

E-mail: anbs@pusan.ac.kr

Key words: Artemisia capillaris, melanogenesis, skin whitening, microphthalmia-associated transcription factor, tyrosinase, tyrosinase related protein 1 and 2 effects with beneficial proliferative properties. However, further studies using in vivo models are required to validate these findings and to examine the effects of these extracts on various molecular pathways.

\section{Introduction}

Melanogenesis is a crucial physiological process that occurs in melanocytes by which the melanosomes that synthesize and store melanin pigment are loaded with melanin and are translocated into the epidermal keratinocytes (1). Melanin biosynthesis is a tightly regulated process, with different pathways controlled by several enzymes and regulators. Tyrosinase is the main enzyme, initiating and regulating melanogenesis. However, tyrosinase-related protein (TRP)-1 and -2 are eumelanogenic enzymes contributing to the completion of the process and acting as modifiers for pathway velocity. TRP-1 and TRP-2 stabilize tyrosinase activity and TRP-1 possibly maintains melanosome structural integrity. Moreover, several regulators are involved in melanin biosynthesis, such as microphthalmia-associated transcription factor (MITF), which is considered the main transcriptional regulator of melanogenesis, functioning as the 'central switchboard' for the routing of various signals involved in the expression of melanogenesis-related genes $(2,3)$.

Melanin pigment plays a crucial role in the protection of epidermal cell DNA from solar ultraviolet radiation damage, and in determining skin, hair and eye color $(4,5)$. Furthermore, it can modulate skin immune responses and serves as a scavenger of reactive oxygen species (ROS), cellular toxins and miscellaneous chemical compounds, preventing further skin damage $(6,7)$. The excessive reduction in melanin production (hypopigmentation) is associated with abnormal melanocyte development and dysfunction $(8,9)$, which subsequently reduces protection from harmful UV radiations present in sunlight. On the other hand, the aberrant excessive production and the accumulation of melanin (hyperpigmentation) can 
lead to the development of skin disorders, such as melasma, post-inflammatory hyperpigmentation, solar lentigo, ephelides and café-au-lait macules (10). Moreover, the overproduction of melanin is recognized not only as a pathological concern, but also as a cosmetic issue. In this regard, individuals from a number of countries in Asia, Africa, South America and the Middle East have decided to reduce skin pigmentation to obtain a lighter skin tone, as fair skin is considered synonymous with youth, health, wealth and beauty in different cultures $(11,12)$. However, hyperpigmentation may be congenital as a result of skin issues/systemic disease or it may be caused by environmental factors (13).

The active agents used to suppress melanin production and lighten the skin for therapeutic or cosmetic purposes are either natural or synthetic, and may function at various levels during melanogenesis. However, several of these agents have undesired adverse effects, such as irritation, rashes, inflamed skin, itchiness, toxicity and pain (14-17), and some of these agents exhibit relatively poor skin permeability $(17,18)$. Therefore, there is a need for new safe and effective skin depigmenting agents to overcome these issues. The use of natural products, including essential oils as functional ingredients in cosmetics and depigmenting agents, has received increasing attention due to the growing interest of consumers in ingredients from natural sources. Moreover, several of these products have multiple pharmacological activities, including anti-melanogenic activity $(19,20)$.

The aim of the present study was to identify naturally-sourced agents for skin whitening purposes and for use in the cosmetic industry with beneficial proliferative properties. For this purpose, the anti-melanogenic activity of essential oils extracted from 10 medicinal plants was evaluated using the B16F10 melanoma cell line by measuring the melanin content. The effects of essential oils with potent anti-melanogenic activity on cell proliferation, protection against $\mathrm{H}_{2} \mathrm{O}_{2}$-induced cell death, and the expression of certain melanogenesis-related proteins, namely MITF, tyrosinase, TRP-1 and TRP-2, were also evaluated.

\section{Materials and methods}

Extraction of essential oils. The hydrodistillation method was used to extract the essential oils from 10 medicinal plants using different plant parts (National Institute of Forest Science; Republic of Korea) (Table I). In brief, $1 \mathrm{~kg}$ of the plant part was mixed with 10 liters of distilled water and heated at $102^{\circ} \mathrm{C}$ using a heating mantle (cat. no. MS-DM608; Misung Scientific Co., Ltd.). The volatile steam was then condensed using a Dean-Stark trap (National Institute of Forest Science; Republic of Korea), and the acquired whole essential oil was dehydrated using anhydrous sodium sulfite and stored at $4^{\circ} \mathrm{C}$ until use.

Cells and cell culture. B16F10 mouse melanoma cells (Korean Cell Line Bank) were cultured in Dulbecco's modified Eagle's medium (DMEM; Welgene Inc.) with or without phenol red supplemented with $10 \%$ fetal bovine serum (FBS; Sigma-Aldrich; Merck KGaA) and $1 \%$ streptomycin/penicillin (Welgene Inc.) under standard culture conditions for $24 \mathrm{~h}$ for recovery. The cultured cells were then treated with the assigned concentrations of the tested essential oils for a further 24 or $72 \mathrm{~h}$ (Table II) for further analysis. For cell viability assay and western blot analysis, the B16F10 cells were cultured in DMEM in 24-well plates at a density of $55 \times 10^{4}$ and $3 \times 10^{5}$ cells/well, respectively, and treated with the essential oils for $24 \mathrm{~h}$. For the 5-bromo-2-deoxyuridine (BrdU) and melanin quantification assays, the B16F10 cells were cultured in DMEM without phenol red in 6-well plates at a density of $1 \times 10^{5}$ cells $/ \mathrm{ml}$ and treated with the essential oils for 24 or $72 \mathrm{~h}$, respectively.

Cell viability assay and determination of half maximal inhibitory concentration $\left(I C_{50}\right)$ values. MTT assay was used to construct a cell viability curve and to determine the $\mathrm{IC}_{50}$ values. The cultured cells were incubated with various concentrations of the essential oils for $24 \mathrm{~h}$. After treatment, the medium containing essential oils was replaced with a solution of $5 \mathrm{mg} / \mathrm{ml} \mathrm{MTT} \mathrm{(Sigma-Aldrich;} \mathrm{Merck} \mathrm{KGaA)} \mathrm{and} \mathrm{incubated}$ at $37^{\circ} \mathrm{C}$ for $2 \mathrm{~h}$. The optical density (OD) was measured at $570 \mathrm{~nm}$ using a microplate reader (BioTek Inc.). Cell viability was calculated using the following formula: OD sample/OD control x100 for each concentration. The cell survival curve and the $\mathrm{IC}_{50}$ value for each treatment were calculated from these values using the SigmaPlot software program (V. 10.0; Systat Software, Inc.).

Measurement of melanin content. For the melanin quantification assay, the cells were pre-incubated with $200 \mathrm{nM} \alpha$-melanocyte-stimulating hormone $(\alpha-\mathrm{MSH}$; Sigma-Aldrich; Merck KGaA) for $1 \mathrm{~h}$ at $37^{\circ} \mathrm{C}$ before adding the essential oils to promote melanin production. The assigned tested essential oils at non-toxic concentrations (Table II) or anti-melanogenic agent arbutin $(250 \mu \mathrm{M})$ were added to the culture medium and incubated for a further $72 \mathrm{~h}$ at $37^{\circ} \mathrm{C}$. $\alpha$-MSH was used without essential oils as a positive control. DMSO alone was used as a standard control. Following treatment, the extracellular melanin content in $200 \mu \mathrm{l}$ of culture media was measured using a microplate reader using a microplate reader (Agilent Technologies, Inc.) at $405 \mathrm{~nm}$. To measure the intracellular melanin content, the cells were washed twice with phosphate-buffered saline (PBS) and collected using trypsinization. Centrifugation at $20,000 \mathrm{xg}$ for $15 \mathrm{~min}$ at $4^{\circ} \mathrm{C}$ was performed, and the melanin pellets were dissolved in $1 \mathrm{~N} \mathrm{NaOH}$ containing 10\% DMSO for $1 \mathrm{~h}$ at $60^{\circ} \mathrm{C}$. The mixed homogenate $(100 \mu \mathrm{l})$ was placed in a 96-well microplate, and the OD values were measured using a microplate reader (Agilent Technologies, Inc.) at $405 \mathrm{~nm}$. The extracellular and intracellular melanin contents per well were calculated and expressed as a percentage of the control.

Assessment of inhibitory effects of essential oil extracts on tyrosinase activity. Mushroom tyrosinase activity assay was performed according to the manufacturer's recommendations. In a 96-well plates, $20 \mu \mathrm{l}$ mushroom tyrosinase $(2,000 \mathrm{U} / \mathrm{ml}$, Sigma-Aldrich; Merck KGaA), $30 \mu$ l essential oil extracts or arbutin (Sigma-Aldrich; Merck $\mathrm{KGaA}$ ) as a positive control, $210 \mu \mathrm{l}$ phosphate buffer $(0.1 \mathrm{M}$; pH 6.8) and $40 \mu \mathrm{l}$ tyrosine (1.5 mM, Sigma-Aldrich; Merck KGaA) were mixed and incubated at $37^{\circ} \mathrm{C}$ for $20 \mathrm{~min}$. The $\mathrm{OD}$ value was then measured using a microplate reader (Agilent Technologies, 
Table I. List of the scientific names, common names, and parts used of the investigated medicinal plants.

\begin{tabular}{llll}
\hline No. & \multicolumn{1}{c}{ Scientific name } & Common name & Parts used \\
\hline 1 & Citrus unshiu & Satsuma orange & Peels \\
2 & Citrus natsudaidai Hayata & Natsumikan & Peels \\
3 & Citrus pseudo gulgul & Hill lemon & Peels \\
4 & Juniperus chinensis L & Chinese juniper & Leaves \\
5 & Juniperus chinensis var. sargentii & Sargent juniper & Leaves \\
6 & Zanthoxylum piperitum & Japanese pepper & Fruits \\
7 & Zanthoxylum schinifolium & Peppertree & Gruits \\
8 & (Siebold \& Zucc) & & Grass clumps \\
9 & Artemisia capillaris & Yin Chen Hao & Leaves \\
10 & Aster glehnii F. Schmidt & Ezo-goma-na & Chinese cinnamon \\
\hline
\end{tabular}

Japanese common name.

Table II. The concentrations of the tested essential oils used in the different assays in the present study.

\begin{tabular}{|c|c|c|c|c|c|}
\hline \multirow[b]{2}{*}{ No. } & \multirow[b]{2}{*}{ Essential oil source } & \multicolumn{4}{|c|}{ Tested concentrations (ppm) } \\
\hline & & Cell viability assay & $\begin{array}{c}\text { Melanin quantification } \\
\text { assays }\end{array}$ & BrdU assay & $\begin{array}{c}\text { Western } \\
\text { blot } \\
\text { analysis }\end{array}$ \\
\hline 1 & Citrus unshiu & $0.31,1.25,5,20$ and 80 & 0.31 and 1.25 & 0.31 and 1.25 & $1.25^{\mathrm{a}}$ \\
\hline 2 & $\begin{array}{l}\text { Citrus natsudaidai } \\
\text { Hayata }\end{array}$ & $0.08,0.31,1.25,5$ and 20 & $0.08,0.31,1.25$ and 5 & - & - \\
\hline 3 & Citrus pseudo gulgul & $0.08,0.31,1.25,5$ and 20 & $0.08,0.31$ and 1.25 & - & - \\
\hline 4 & Juniperus chinensis L & $0.08,0.31,1.25,5$ and 20 & $0.08,0.31$ and 1.25 & $0.08,0.31$ and 1.25 & $1.25^{\mathrm{a}}$ \\
\hline 5 & $\begin{array}{l}\text { Juniperus chinensis } \\
\text { var. sargentii }\end{array}$ & $0.31,1.25,5,20$ and 80 & 0.31 & - & - \\
\hline 6 & Zanthoxylum piperitum & $0.08,0.31,1.25,5$ and 20 & $0.08,0.31,1.25$ and 5 & $0.08,0.31,1.25$ and 5 & $5^{\mathrm{a}}$ \\
\hline 7 & $\begin{array}{l}\text { Zanthoxylum schinifolium } \\
\text { (Siebold \& Zucc) }\end{array}$ & $0.31,1.25,5,20$ and 80 & $0.31,1.25$ and 5 & - & - \\
\hline 8 & Artemisia capillaris & $0.08,0.31,1.25,5$ and 20 & $0.08,0.31,1.25$ and 5 & $0.08,0.31,1.25$ and 5 & $5^{\mathrm{a}}$ \\
\hline 9 & Aster glehnii F. Schmidt & $0.31,1.25,5,20$ and 80 & 0.31 and 1.25 & - & - \\
\hline 10 & Cinnamomum cassia & $0.08,0.31,1.25,5$ and 20 & $0.08,0.31,1.25$ and 5 & - & - \\
\hline
\end{tabular}

${ }^{a}$ These concentrations were also used to assess the protective effects of essential oils against $\mathrm{H}_{2} \mathrm{O}_{2}$-induced cell death.

Inc.) at $490 \mathrm{~nm}$. The tyrosinase activity in the samples were expressed using the following formula: OD sample/OD control x100.

Measurement of cell proliferation. BrdU assay was carried out using a cell proliferation ELISA BrdU kit (Roche Diagnostics) according to the manufacturer's recommendations. In brief, following the treatment period with the assigned concentrations of the essential oils, $100 \mu \mathrm{l}$ BrdU solution $(100 \mu \mathrm{M})$ were added to each well in $1 \mathrm{ml}$ medium, and the plates were then incubated at $37^{\circ} \mathrm{C}$ for $4 \mathrm{~h}$. Subsequently, the cells were fixed using $1 \mathrm{ml}$ FixDenat (Roche Diagnostics) in each well for
30 min and incubated with the kit-supplied anti-BrdU antibody (1:100; Roche Diagnostics) for $90 \mathrm{~min}$ at room temperature. After washing, the cells were incubated with $500 \mu$ l substrate for $20 \mathrm{~min}$ at room temperature, and $125 \mu \mathrm{l} \mathrm{H}_{2} \mathrm{SO}_{4}(1 \mathrm{M})$ were added. The plates were analyzed at $450 \mathrm{~nm}$ using a spectrometer (Agilent Technologies, Inc.).

Assessment of the protective effects of the essential oils against $\mathrm{H}_{2} \mathrm{O}_{2}$-induced cell death. B16F10 cells were cultured in DMEM containing the assigned concentrations of the tested essential oils (Table II) for $24 \mathrm{~h}$, as described above. $\mathrm{H}_{2} \mathrm{O}_{2}$ (Sigma-Aldrich; Merck KGaA) was then added at a final 
concentration of $400 \mu \mathrm{M}$ for $4 \mathrm{~h}$. Cell viability was assessed using MTT assay as aforementioned.

Western blot analysis. Protein samples from the B16F10 cells treated with the assigned concentrations of the essential oils for $24 \mathrm{~h}$ were extracted using Pro-Prep solution (iNtRON Biotechnology Inc.) according to the manufacturer's protocol. The concentration of protein was determined by performing a bicinchoninic acid assay. Subsequently, $5 \mu \mathrm{g}$ protein were loaded and separated using sodium dodecyl sulfate-polyacrylamide gel electrophoresis on 8-10\% gels and transferred onto nitrocellulose membranes (Daeillab Lab Service Co., Ltd.) using the wet transfer system. The membranes were blocked for $2 \mathrm{~h}$ with 5\% skimmed milk (BD Biosciences) in PBS with $0.05 \%$ Tween-20 (PBST) at room temperature. Subsequently, the membranes were incubated with antibodies against MITF (1:300; cat. no. sc-56725; Santa Cruz Biotechnology, Inc.), tyrosinase (1:300; cat. no. sc-20035; Santa Cruz Biotechnology, Inc.), TRP-1 (1:300; cat. no. sc-25543; Santa Cruz Biotechnology, Inc.), TRP-2 (1:300; cat. no. sc-25544; Santa Cruz Biotechnology, Inc.) and $\beta$-actin (1:3,000; cat. no. \#4967; Cell Signaling Technology, Inc.), which served as an internal control overnight at $4{ }^{\circ} \mathrm{C}$, followed by incubation with horseradish peroxidase-conjugated secondary antibodies (1:5,000; cat. nos. ADI-SAB-100 and ADI-SAB-300; Enzo Life Science Inc.) in 5\% skimmed milk in PBST for $1 \mathrm{~h}$ at room temperature. Luminol reagent (Bio-Rad Laboratories, Inc.) was used to visualize antibody binding. The blots were scanned using Gel Doc 1000, version 1.5 (Bio-Rad Laboratories, Inc.), and band intensities were normalized to $\beta$-actin levels.

Statistical analyses. Data are presented as the mean \pm standard deviation (SD). Data were analyzed using one-way analysis of variance (ANOVA) with SPSS 10.10 standard version (IBM Corp.). Means obtained from three independent experiments were evaluated using one-way ANOVA and Tukey's post hoc t-test for multiple comparisons. A value of $\mathrm{P}<0.05$ was considered to indicate a statistically significant difference.

\section{Results}

Effects of the tested essential oils on cell viability. Cell viability assays were conducted using a wide range of concentrations (0.31-80 ppm) for the essential oils extracted from Citrus unshiu (C. unshiu), Juniperus chinensis var. sargentii (J. chinensis var. sargentii), Zanthoxylum schinifolium (Siebold \& Zucc) (Z. schinifolium) and Aster glehnii F. Schmidt (A. glehnii), and from 0.08 to $20 \mathrm{ppm}$ for the essential oils extracted from Citrus natsudaidai Hayata (C. natsudaidai), Citrus pseudo gulgul (C. pseudo gulgul), Juniperus chinensis (J. chinensis L.), Zanthoxylum piperitum (Z. piperitum), Artemisia capillaris (A. capillaris) and Cinnamomum cassia (C. cassia) to screen their toxic effects on B16F10 cells. The tested essential oils exhibited variable toxicity levels in the B16F10 cells, as revealed by the cell viability curves and $\mathrm{IC}_{50}$ values (Fig. 1). The essential oils extracted from $C$. unshiu exhibited the highest toxicity level ( $\left.\mathrm{IC}_{50}, 5.388 \mathrm{ppm}\right)$, whereas the essential oil extracted from A. glehnii exhibited the lowest toxicity level ( $\mathrm{IC}_{50}, 30.846 \mathrm{ppm}$ ) (Fig. 1).
Effect of essential oils on melanin content. A set of non-toxic concentrations of the tested essential oils was used to investigate their anti-melanogenic activity in B16F10 cells. The extracellular and intracellular melanin contents were quantified after culturing the cells with the assigned treatments for $72 \mathrm{~h}$ (Fig. 2). The extracellular and intracellular melanin contents were significantly higher $(\mathrm{P}<0.05)$ in the positive control group ( $\alpha-\mathrm{MSH})$ than in the other treatment groups. However, arbutin treatment significantly decreased the extracellular and intracellular melanin content compared to that in the positive control group $(\mathrm{P}<0.05)$. Of note, the essential oils extracted from $C$. unshiu, J. chinensis L., Z. piperitum and $A$. capillaris significantly decreased the extracellular melanin contents at all concentrations tested compared to the positive control group $(\mathrm{P}<0.05)$, excluding the concentration of $0.31 \mathrm{ppm}$ for J. chinensis L. The highest concentrations of these essential oils decreased the extracellular melanin content by $20,38.8,21$ and $53.5 \%$ compared with the positive control group, respectively. However, only the elevated concentrations of $Z$. piperitum and A. capillaris significantly decreased the intracellular melanin content $(\mathrm{P}<0.05)$ compared to that in the positive control group by 14.4 and $17.5 \%$, respectively (Figs. 2 and 3). Of note, none of these essential oils significantly altered the tyrosinase activity (Fig. S1).

Effect of essential oils on B16F10 cell proliferation. Among the 10 essential oils examined in the present study, only four essential oils with anti-melanogenic activity (C. unshiu, $J$. chinensis L., Z. piperitum, and A. capillaris) were selected to investigate their effects on cell proliferation using BrdU assay. In general, the essential oils extracted from $Z$. piperitum and A. capillaris enhanced cell proliferation, although only $A$. capillaris extract at a concentration of $1.25 \mathrm{ppm}$ significantly $(\mathrm{P}<0.05)$ increased cell proliferation by $18.7 \%$ compared to that in the control group. However, the highest concentrations tested for the C. unshiu and J. chinensis L. extracts significantly decreased cell proliferation by 11.5 and $10.1 \%$, respectively $(\mathrm{P}<0.05$; Fig. 4).

Assessment of the protective effects of the essential oils against $\mathrm{H}_{2} \mathrm{O}_{2}$-induced cell death. The protective effects of the essential oils extracted from $C$. unshiu, J. chinensis L., $Z$. piperitum, and A. capillaris against $\mathrm{H}_{2} \mathrm{O}_{2}$-induced cell death were assessed using MTT assay. The most effective concentration of the essential oils for an anti-melanogenic effect was used for MTT assay. As shown in Fig. 5, only the essential oil extracted from A. capillaris attenuated the effects of $\mathrm{H}_{2} \mathrm{O}_{2}$ on cell death induction and significantly increased cell viability in the presence of $\mathrm{H}_{2} \mathrm{O}_{2}$ in the culture media compared to the other essential oils $(\mathrm{P}<0.05)$.

Effects of the essential oils on the translational levels of melanogenesis-related genes. The effects of the four essential oils extracted from $C$. unshiu, J. chinensis L., Z. piperitum, and A. capillaris on the MITF, tyrosinase, TRP-1 and TRP-2 translational levels in B16F10 cells were examined using western blot analysis. The most effective concentration of the essential oils for an anti-melanogenic effect was used in western blot analysis. The essential oil extracted from A. capillaris at a concentration of 5 ppm significantly decreased the 

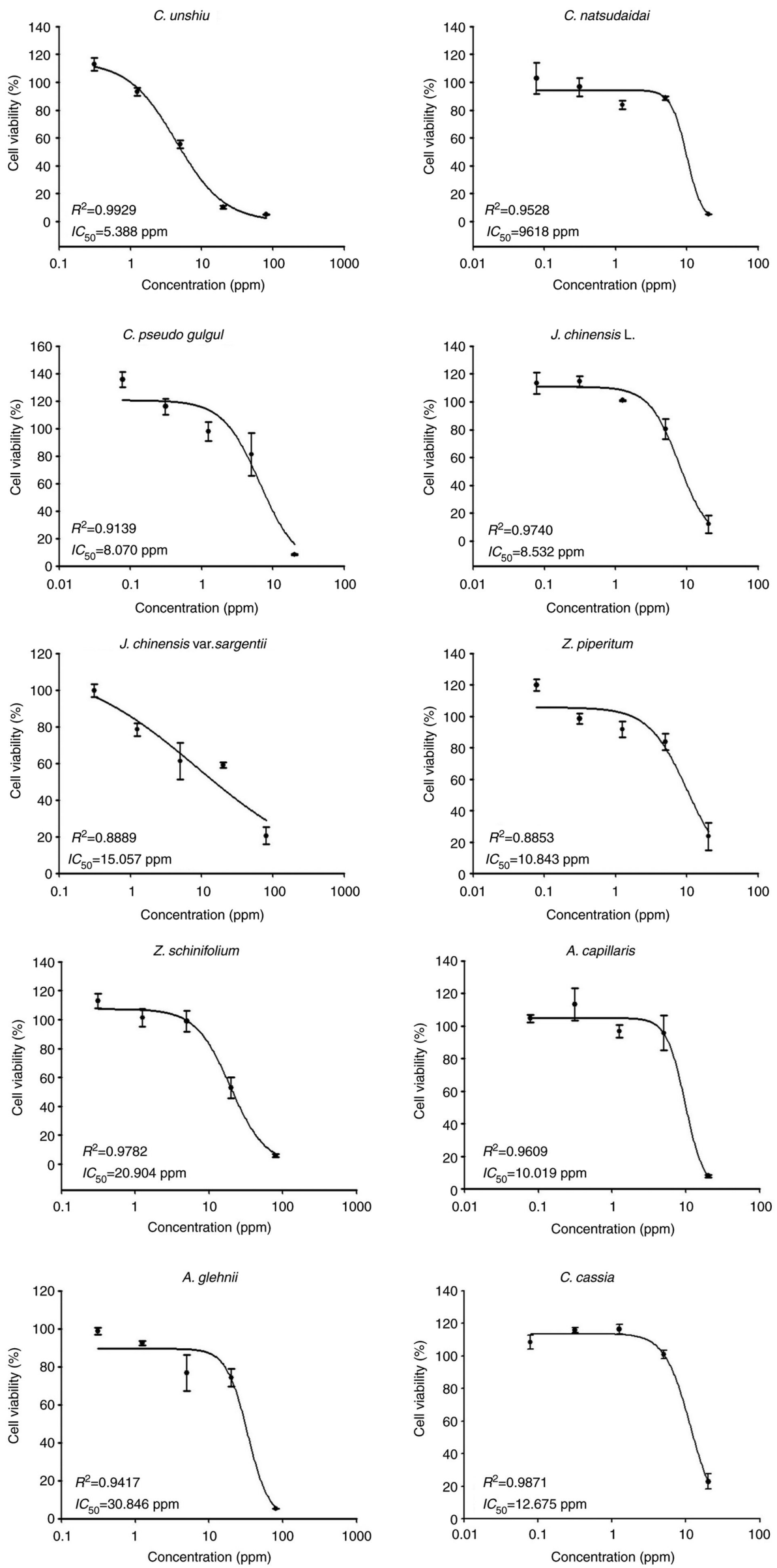

Figure 1. Cell viability curves and $\mathrm{IC}_{50}$ values of the tested essential oils. $\mathrm{IC}_{50}$, the concentration of the essential oil in the culture media that killed $50 \%$ of the B16F10 melanoma cells. 


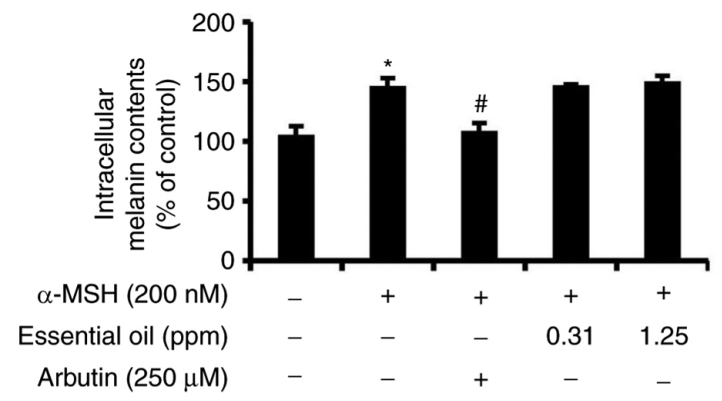

C. unshiu

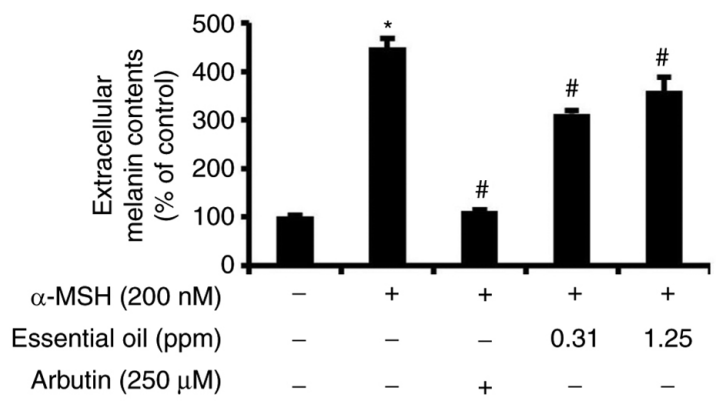

C. natsudaidai
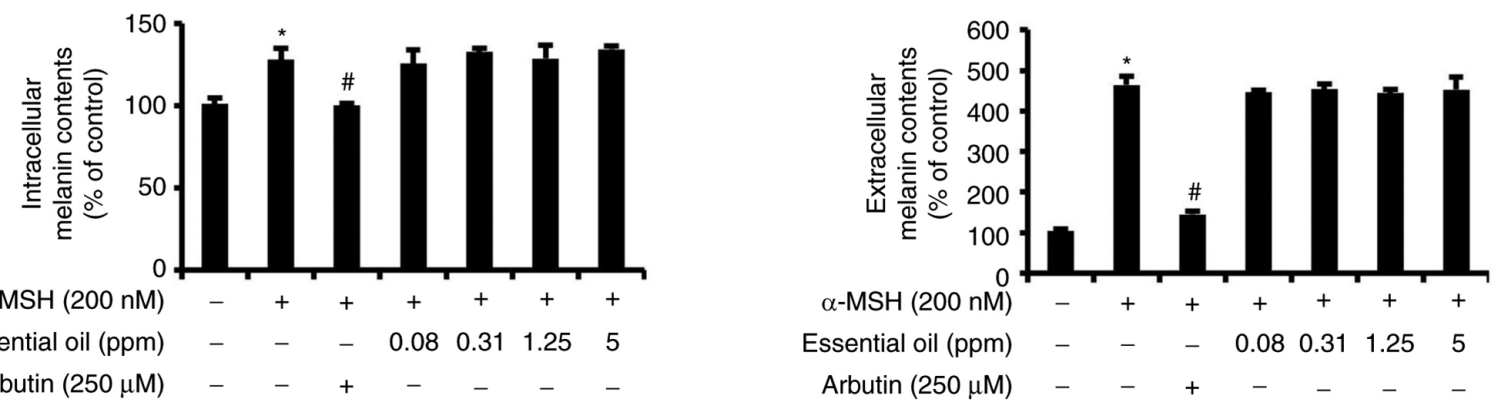

C. pseudo gulgul
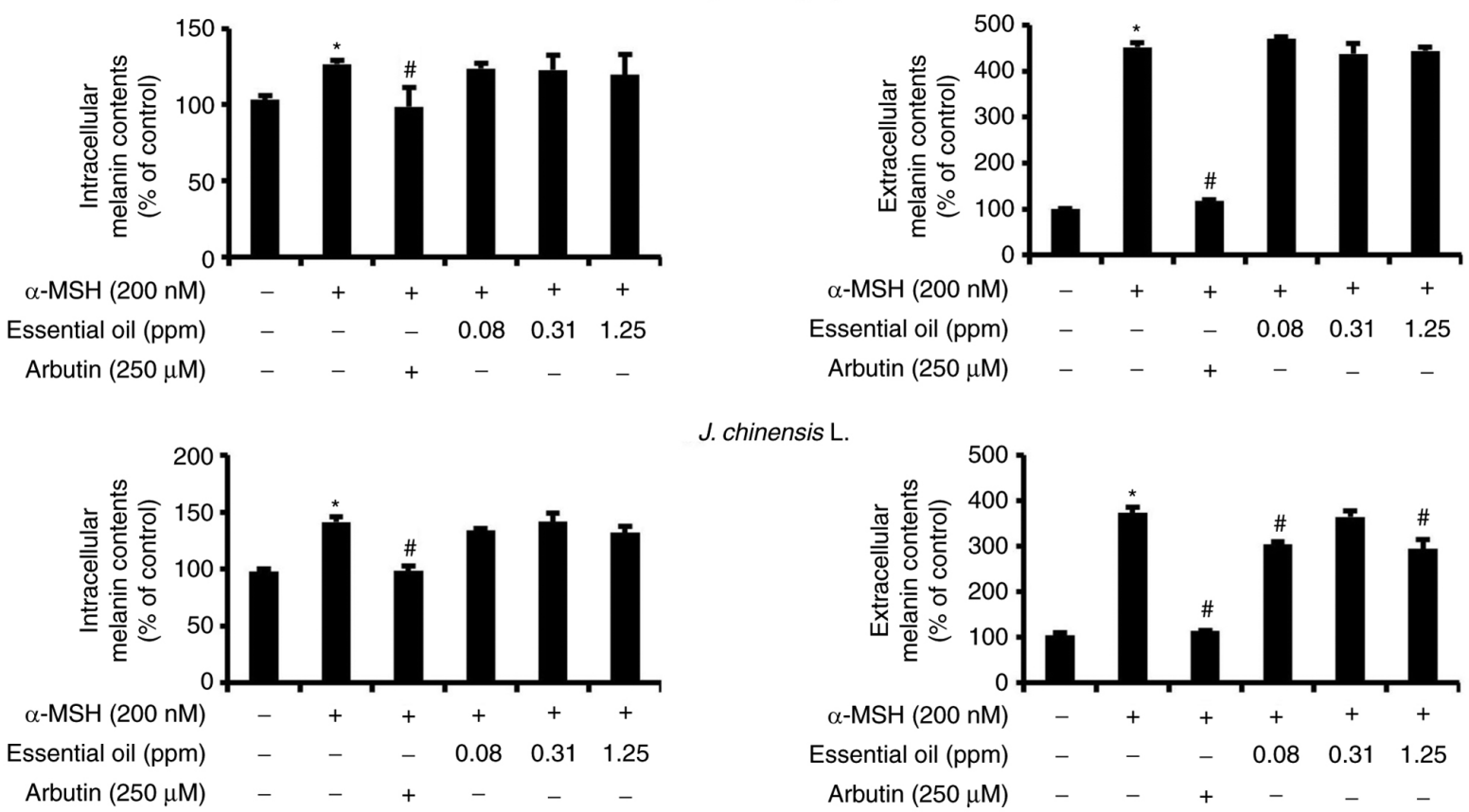

J. chinensis $\mathrm{L}$.

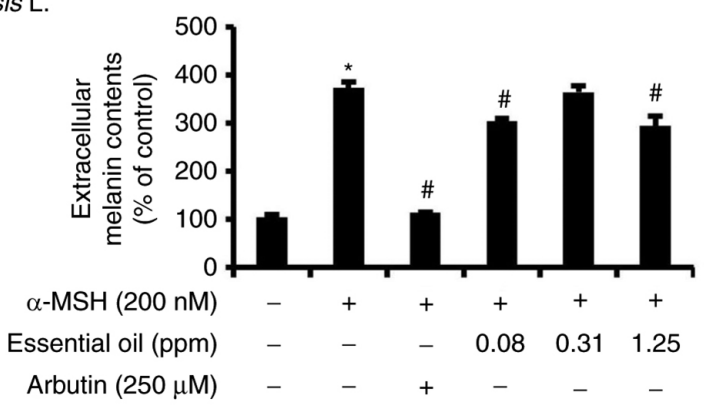

Figure 2. Continued.

TRP-1 protein level by $\sim 68 \%$ compared to that in the control group $(\mathrm{P}<0.05)$. However, the other essential oils did not induce any significant changes in the protein levels of tyrosinase, TRP-1 and TRP-2 (Figs. 6 and S2). Among the proteins related to melanogenesis, only MITF exhibited double bands. The upper band has been assigned as a shift of the lower band due to phosphorylation (21). However, none of the essential oils altered the expression levels of MITF (Figs. 6 and S2).

\section{Discussion}

Essential oils extracted from 10 medicinal plants were assessed in the present study to determine their anti-melanogenic activities using B16F10 cell line model. These plants represent various groups of medicinal plants that are widely distributed in a number of Asian countries and have a long history of use in folk medicine to treat various diseases. Moreover, over the past few decades, increased attention has been directed towards the use of functional components from these plants in biomedical applications to treat various diseases, such as cancer (22-25), allergies (26), dermatopathology $(27,28)$ and other diseases (29-32). However, little is known about their effects and functions as natural anti-melanogenic agents.

Melanogenesis is a complex and multistep process that results in melanin formation. Therefore, the measurement of the melanin content is a direct strategy which can be used to 


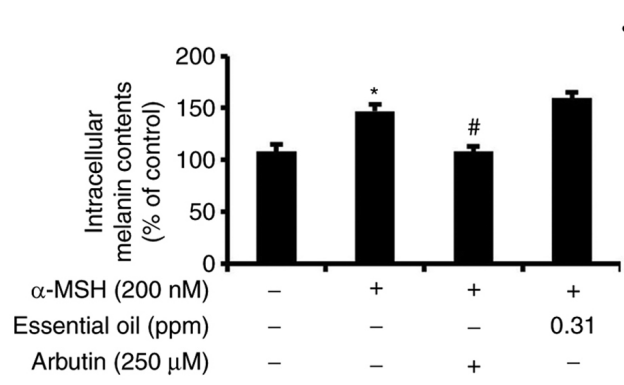

J. chinensis var. sargentii

Arbutin $(250 \mu \mathrm{M})$
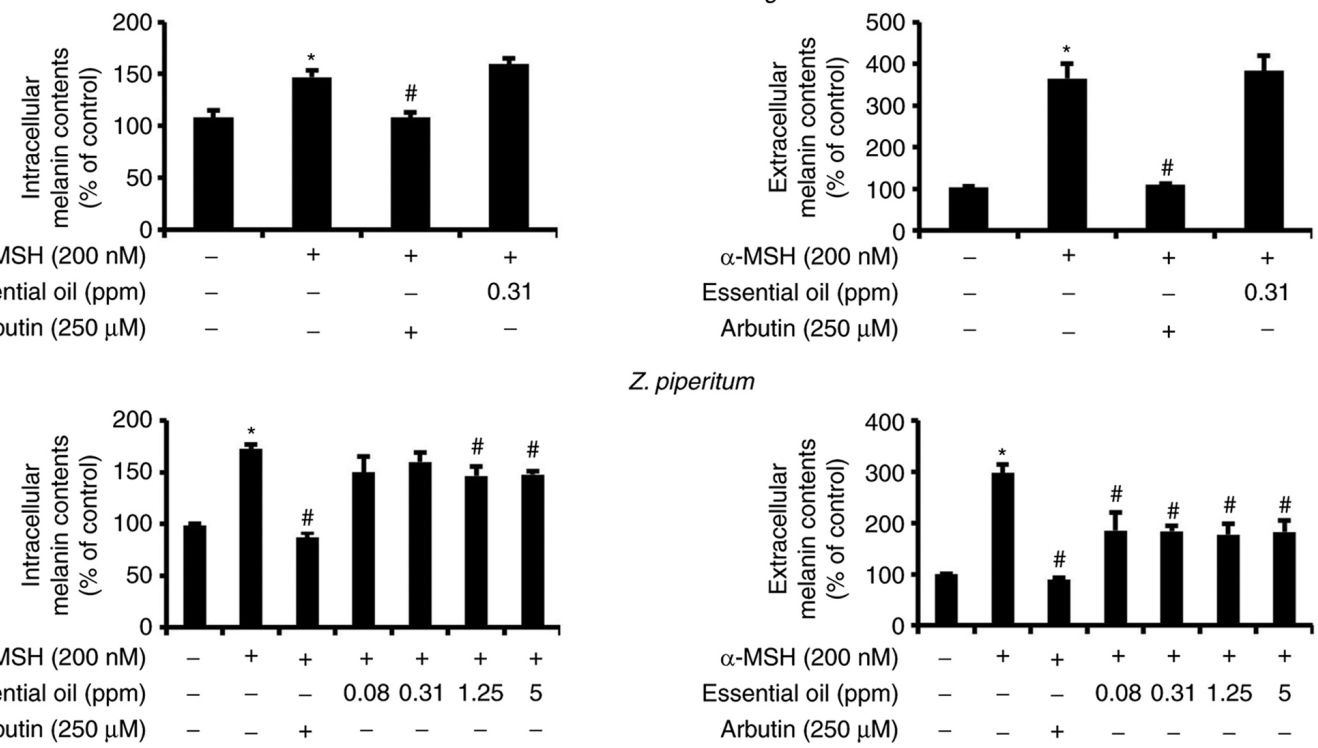

Z. piperitum

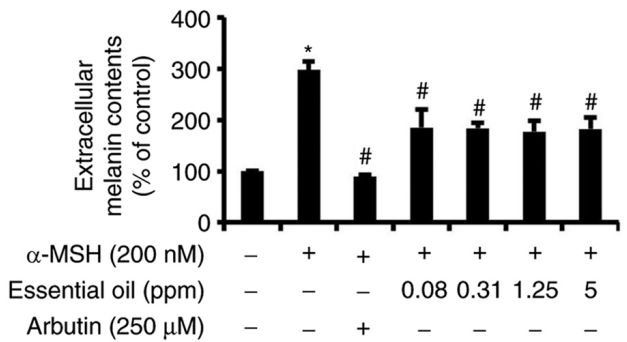

Z. schinifolium
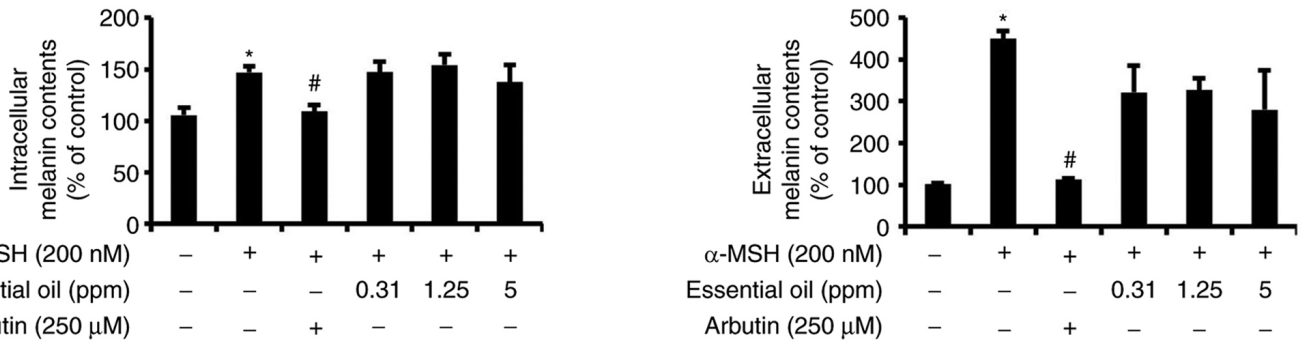

A. capillaris
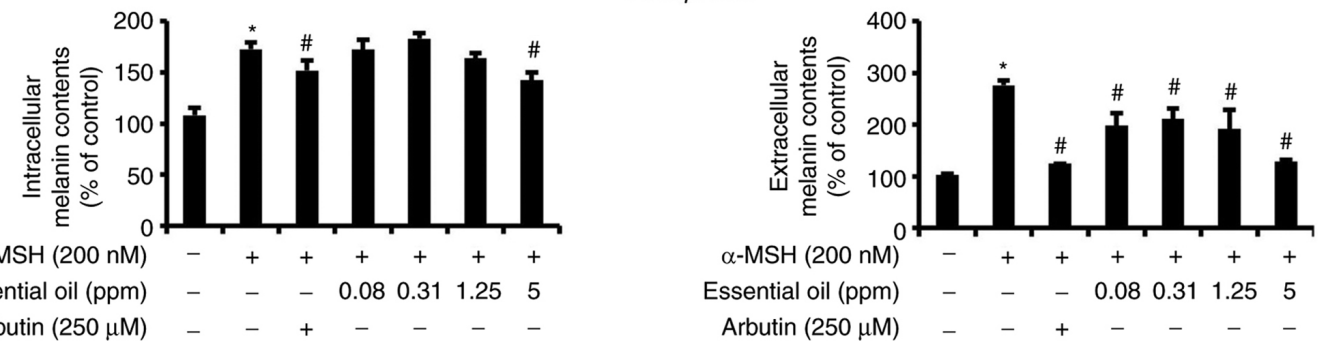

A. glehnii
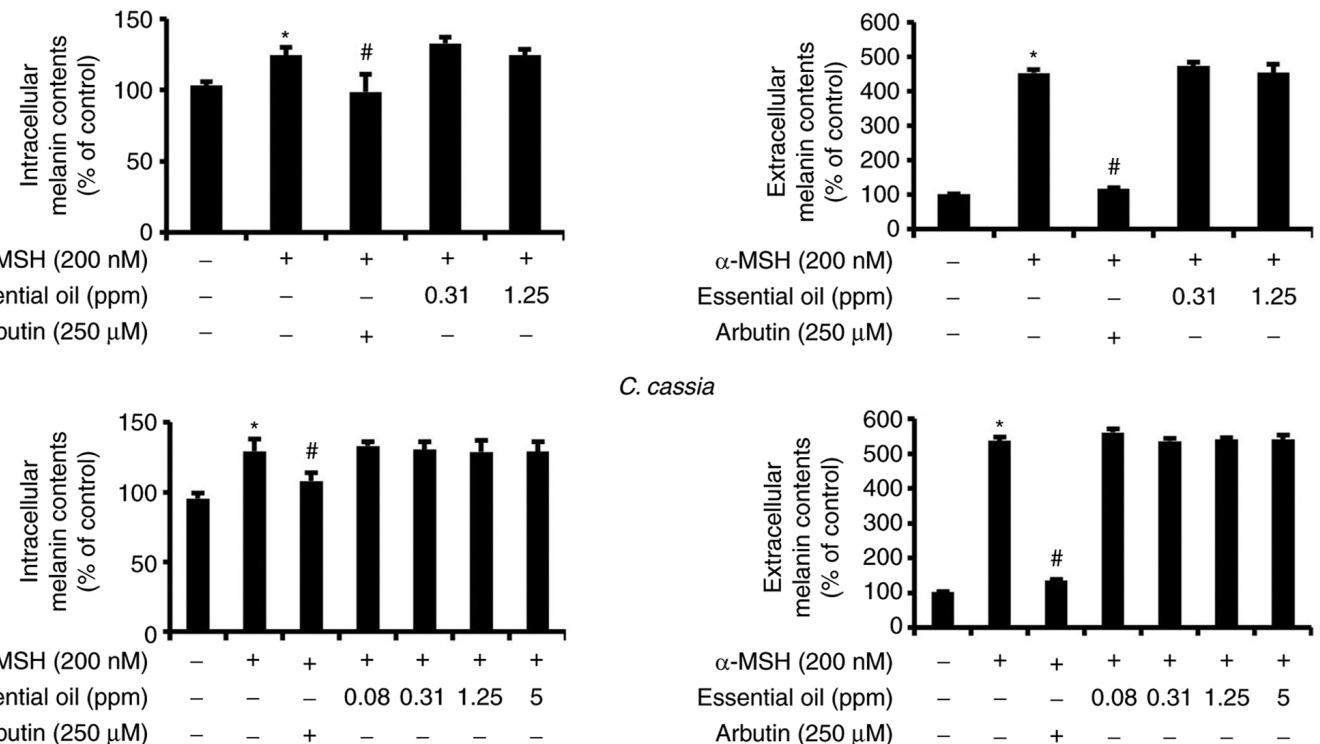

C. cassia

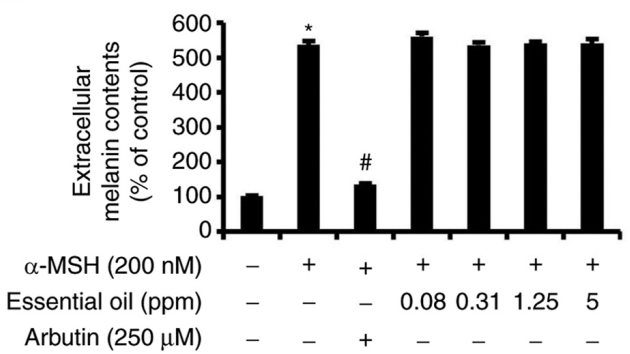

Figure 2. Intracellular and extracellular melanin contents measured following the indicated treatments of the B16F10 melanoma cells. Each value for melanin contents was calculated relative to that of the control group. Values represent the mean $\pm \mathrm{SD}$ of three independent experiments. "P $<0.05$, significant difference between the control and $\alpha$-MSH group; ${ }^{\prime} \mathrm{P}<0.05$, significant difference compared to the group treated with $\alpha$-MSH only. $\alpha$-MSH, $\alpha$-melanocyte-stimulating hormone. 

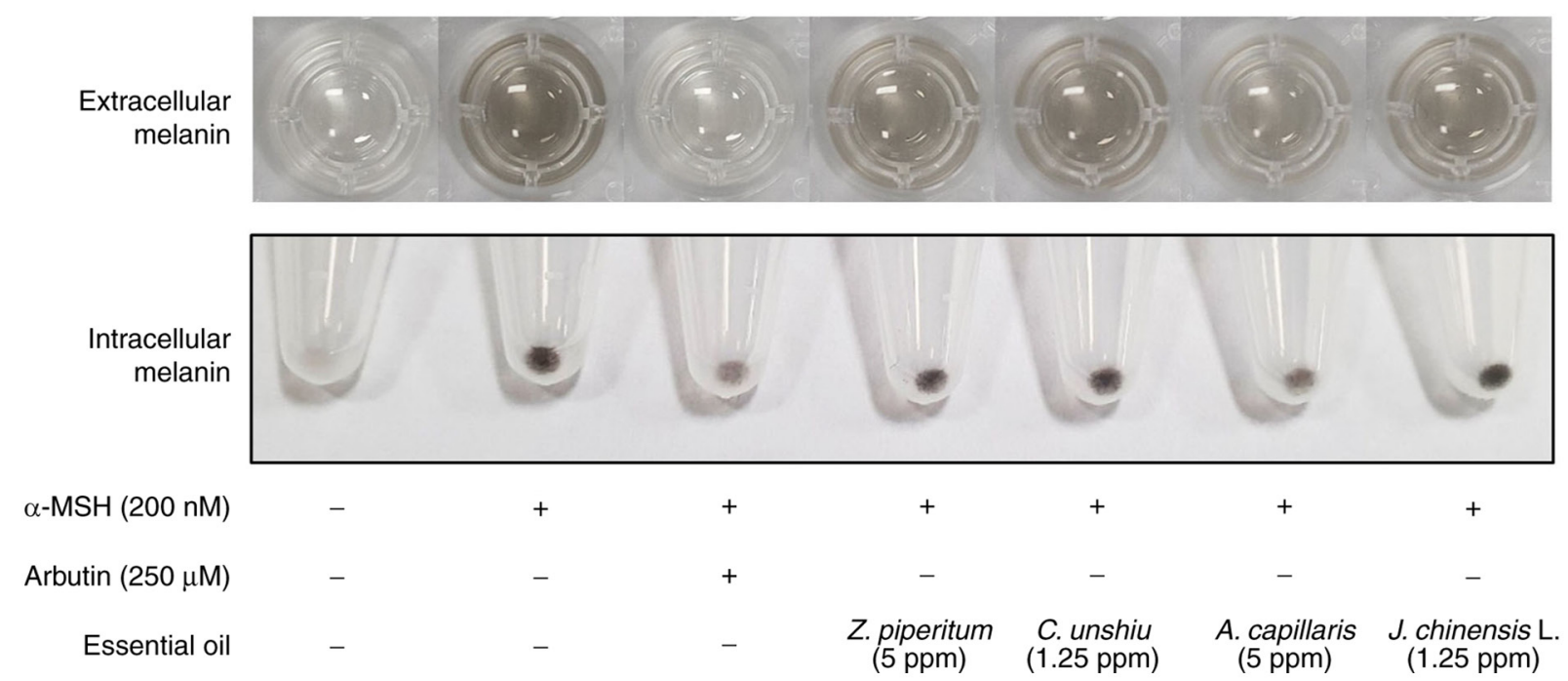

Figure 3. Effects of C. unshiu, J. chinensis L., Z. piperitum and A. capillaris extracts on $\alpha$-MSH-induced melanogenesis. B16F10 Cells were incubated with the assigned concentrations of the essential oils extracts or arbutin $(250 \mu \mathrm{M})$ in the presence of $\alpha$-MSH (200 $\mathrm{nM})$ for $72 \mathrm{~h}$, collected in a microfuge tube, and photographed. Experiments were performed three times with similar results, and a typical image is presented. $\alpha$-MSH, $\alpha$-melanocyte-stimulating hormone.

assess the melanogenic activity. It has been reported that in an in vitro culture system, melanin is synthesized intracellularly and is then transported into the surrounding culture medium $(33,34)$. In the present study, the extracellular and intracellular melanin contents were determined simultaneously to measure the total amount of melanin synthesized under various treatment conditions in B16F10 cells. The anti-melanogenic effects of the essential oils were further examined on the human melanoma cell line, A375SM; however, when treated with $\alpha-\mathrm{MSH}$ as a positive control, the cells did not produce a sufficient amount of melanin to evaluate the anti-melanogenic effects (data not shown). Among the essential oil extracts examined, only four essential oils from C. unshiu, J. chinensis L., Z. piperitum and A. capillaris successfully decreased melanogenesis compared to the other extracts, which reflects their potency as anti-melanogenic agents. In agreement with these findings, previous studies have reported the inhibitory effects of some fractions extracted from these four plants on melanin formation using various cell models $(31,35-37)$. Notably, the non-toxic concentrations of all essential oils used in the present study, which inhibited melanin formation, were very low compared to the fraction concentrations used in a previous study, which reached up to $100 \mu \mathrm{g} / \mathrm{ml}$ (36). Although the whole extracts of the essential oils exerted beneficial effects on melanogenesis, active substances were not evaluated in the present study. Therefore, further studies on the active compounds for each essential oil are warranted. However, using the whole essential oils has an advantage over purified components as they have multi-pharmacological activities, and the different components may exert a synergistic or potentiating effects and be important for the bioactivity of the essential oils $(38,39)$. Moreover, unlike previous studies (35-37), the present study used the hydrodistillation method for essential oil extraction, avoiding the hazards of organic solvents and emulsion formation using other methods (40). To $\mathrm{v}$ further alidate efficiency of the extracts, their effects on cell proliferation were assessed using BrdU assay, which established the positive effects of two extracts, Z. piperium and A. capillaris, at specific concentrations on cell proliferation. Additionally, as the skin, more than other tissues, is exposed to numerous external stresses generating several types of ROS, such as $\mathrm{H}_{2} \mathrm{O}_{2}$ that is also produced as a response to a multitude of very complex cellular events causing various deleterious effects and apoptosis in keratinocytes $(41,42)$, the protective effects of $A$. capillaris against $\mathrm{H}_{2} \mathrm{O}_{2}$-induced cell death were also examined. Of note, $A$. capillaris was also able to significantly reduce $\mathrm{H}_{2} \mathrm{O}_{2}$-induced cell death, suggesting that it is an anti-melanogenic agent with proliferative and antioxidant properties. Hong et al (43) reported that ethyl acetate fraction from A. capillaris exerted significant ROS scavenging and protective effects against oxidative DNA.

The anti-melanogenic effects of the extracted essential oils on the B16F10 cell line were also investigated at the molecular level by assessing the MITF, tyrosinase, TRP-1, and TRP-2 protein expression levels using western blot analysis. Although the four essential oils tested successfully decreased the synthesized melanin content, they did not affect the expression levels of MITF, tyrosinase and TRP-2 proteins, or even tyrosinase activity, and only the essential oil extracted from A. capillaris significantly decreased the expression level of TRP-1 compared to that in the control group. Although tyrosinase is the key enzyme in melanogenesis, TRP-1 is considered an eumelanogenic enzymes with a vital role in the completion of melanogenesis. TRP-1 is a protein producing eumelanin in the last stage of the melanogenesis. Eumelanin is the most common type of melanin comprising cross-linked 5,6-dihydroxyindole (DHI) and 5,6-dihydroxyindole-2-carboxylic acid (DHICA). TRP-1 induces the oxidative conversion of DHICA to indole-5,6-quinone-2-carboxylic acid, which is a structural unit of eumelanin $(2,3)$. Therefore, the overexpression of TRP-1 causes skin color to darken (44). Eberle et al (45) examined the expression levels of tyrosinase family genes in melanoma and normal melanocyte human cell lines and found that the expression levels of tyrosinase and TRP-2 are 

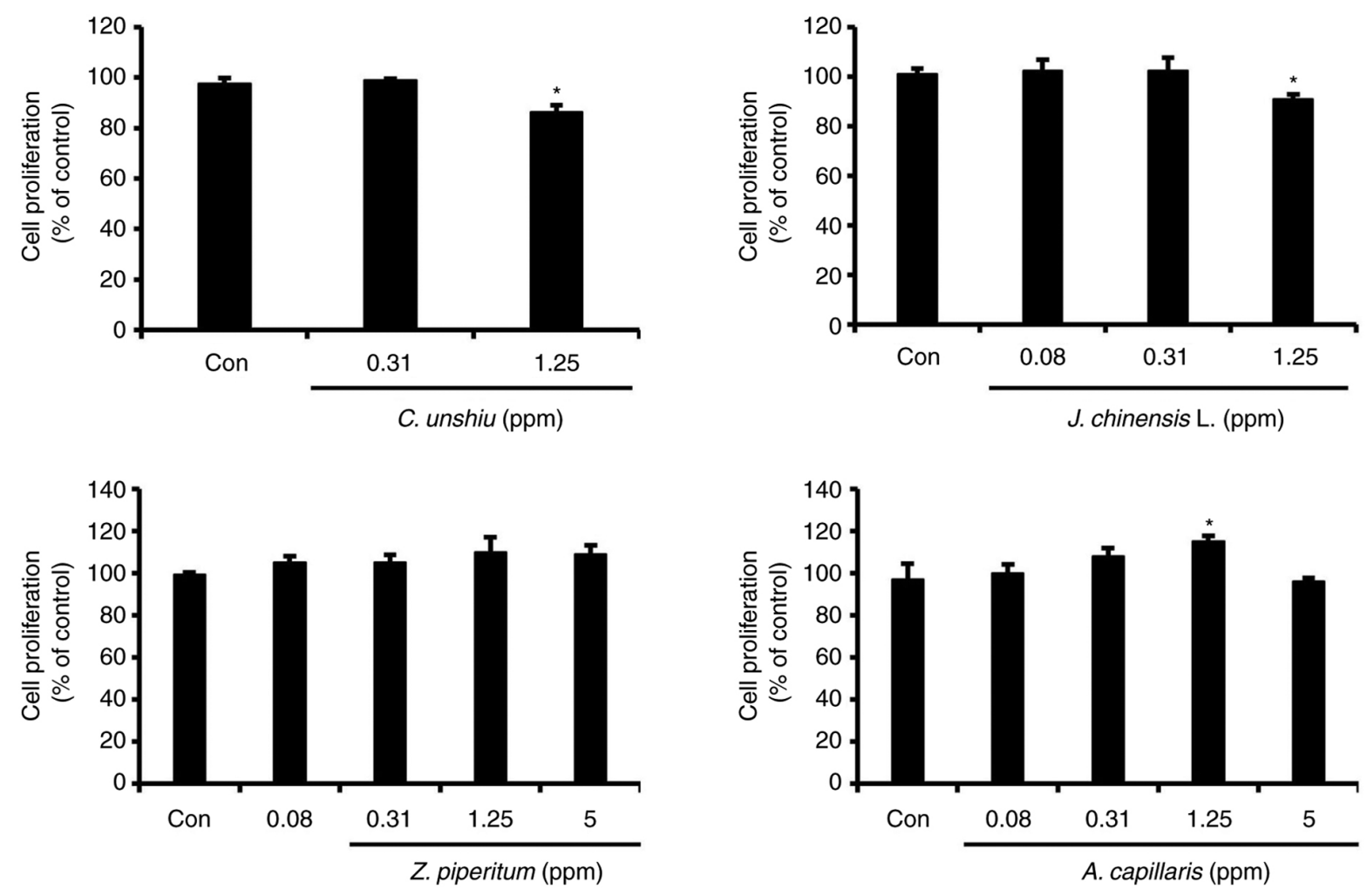

Figure 4. Effects of the essential oils on B16F10 melanoma cell proliferation. ${ }^{*} \mathrm{P}<0.05$, significant difference compared to the control.

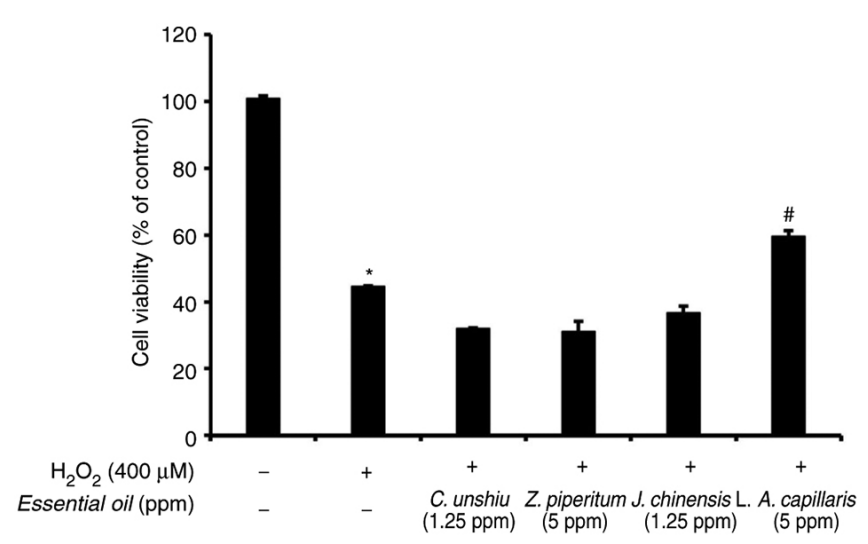

Figure 5. Protective effects of the essential oils against the $\mathrm{H}_{2} \mathrm{O}_{2}$-induced death of B16F10 cells as revealed using MTT assay. ${ }^{*} \mathrm{P}<0.05$, significant difference between the control and the group treated with $\mathrm{H}_{2} \mathrm{O}_{2}$ only; ${ }^{\prime \prime} \mathrm{P}<0.05$, significant difference compared to the group treated with $\mathrm{H}_{2} \mathrm{O}_{2}$ only.

regulated differently than TRP-1. Accordingly, in the present study, A. capillaris at a concentration of the $5 \mathrm{ppm}$ did not affect the MITF, tyrosinase and TRP-2 expression levels or tyrosinase activity, whereas it significantly decreased TRP-1 expression compared to that in the control group. It appears that $A$. capillaris inhibits melanogenesis via a tyrosinase-independent pathway. Therefore, any materials or components that suppress TRP-1 expression may affect melanogenesis by reducing the oxidation of DHICA to a carboxylated indole-quinone. The findings of the present study suggest that the low expression of TRP-1 can reduce melanin synthesis. The present study initially examined various concentrations of $A$. capillaris $(0.08,0.13,1.25$ and $5 \mathrm{ppm}$ ) on cell viability and melanin synthesis. While the concentrations $<5 \mathrm{ppm}(0.08,0.13$ and $1.25 \mathrm{ppm}) \mathrm{did}$ not affect cytotoxicity, these concentrations did not reduce intracellular melanin contents. The concentration of $5 \mathrm{ppm}$ exerted the optimal effect on melanin synthesis, and significantly decreased the extracellular and intracellular melanin contents by 53.5 and $17.5 \%$, respectively compared to the control group. Therefore, this concentration was used to examine the effect of A.capillaris against the protein expression levels of TRP-1. Although the C. unshiu, J. chinensis L. and $Z$. piperitum extracts decreased the melanin content, none of them altered the translational level of the proteins involved in melanin synthesis. These extracts appear to exert their effects on melanogenesis via mechanisms different from those of A. capillaris. As melanogenesis is a tightly regulated process that includes various enzymes and other factors controlling different pathways, materials that exert an inhibitory effect on any of these factors are anticipated to inhibit melanogenesis.

In conclusion, the essential oils extracted from $C$. unshiu, J. chinensis L., Z. piperitum and A.capillaris using the hydrodistillation method inhibited melanin synthesis. A. capillaris extract was the most potent inhibitor of melanin synthesis, with good potential to enhance cell viability and anti- $\mathrm{H}_{2} \mathrm{O}_{2}$ activity. A. capillaris extract inhibited melanin synthesis by downregulating the TRP-1 expression level. The present study did not perform animal experiments to reveal the effects of the essential oils. Further animal studies are thus required to address the systemic effects of the essential oils. However, in general, animal experiments to evaluate the functional effects of certain materials on the skin are prohibited for animal protection. Even though the present study did not determine the 


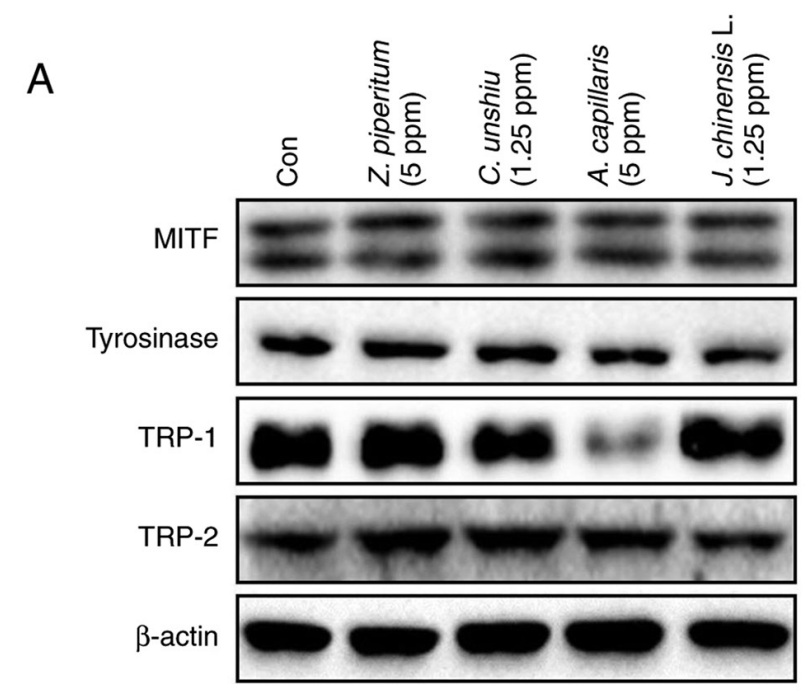

B

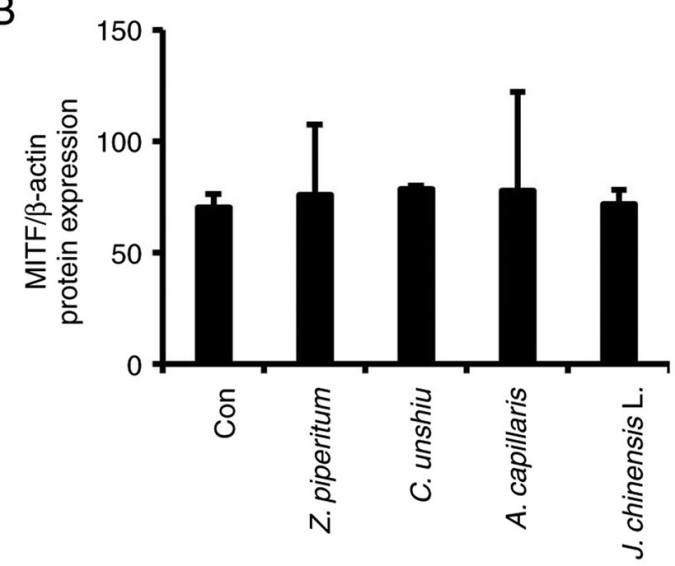

D

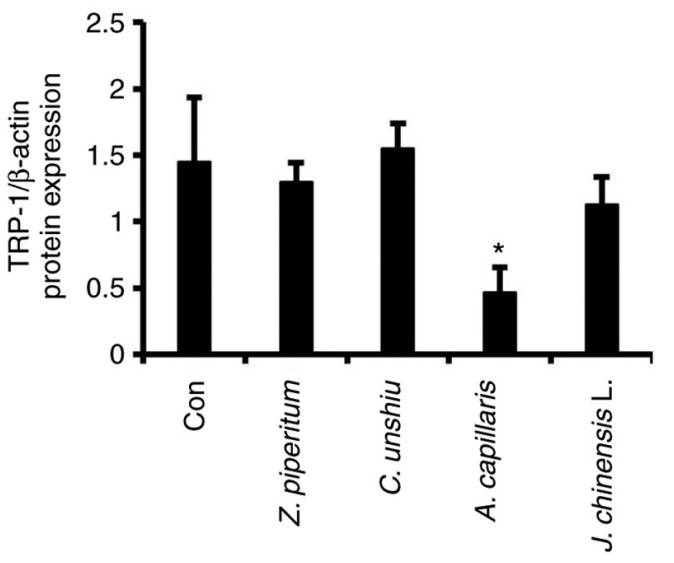

C

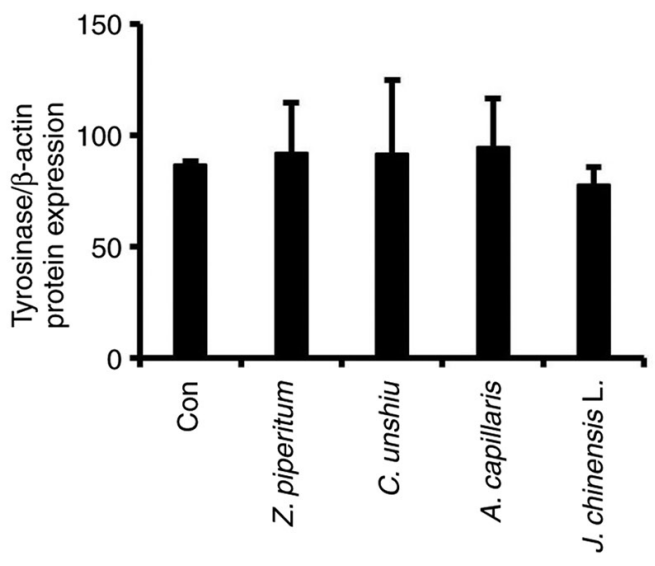

$E$

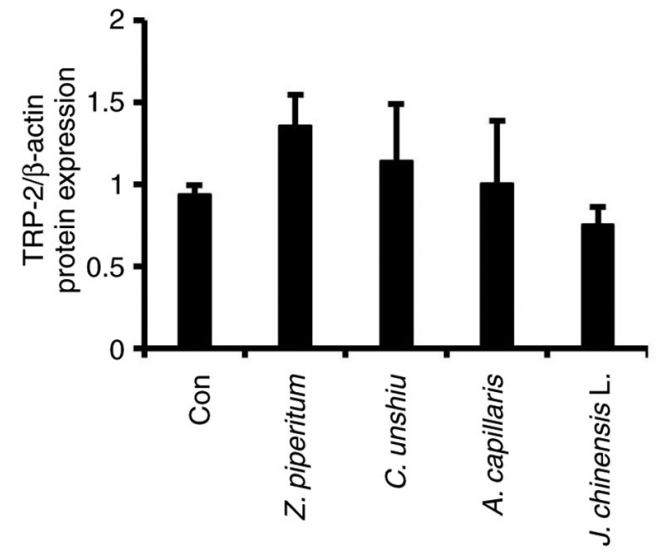

Figure 6. Translational level of melanogenesis-related genes in B16F10 cells treated with different essential oils. (A) Translational levels of melanogenesis-related genes examine using western blot analysis. The expression levels of (B) MITF, (C) tyrosinase, (D) TRP-1, and (E) TRP-2are represented as schematic graphs and normalized to $\beta$-actin levels. Data are expressed as the mean \pm SD. "P $<0.05$, significant difference compared to the control. MITF, microphthalmia-associated transcription factor; TRP, tyrosinase related protein.

effects of the extracts in in vivo conditions, these four essential oil extracts, particularly A. capillaris, may be considered as natural anti-melanogenic agents with beneficial proliferative properties for the treatment of skin pigmentary disorders and for skin whitening in the cosmetic industry. However, future studies using in vivo models are required for further validation and to investigate the effects of these extracts at the molecular level through various mechanisms and pathways.

\section{Acknowledgements}

Not applicable.

\section{Funding}

The present study was performed with the support of the National Institute of Forest Science (Project 
no. FP0702-2016-03-2020) and was partially supported by the BK21 FOUR Program (grant no. F20YY8109033) through the National Research Foundation of Korea (NRF), funded by the Ministry of Education, Korea.

\section{Availability of data and materials}

The datasets used and/or analyzed during the current study are available from the corresponding author on reasonable request.

\section{Authors' contributions}

MJK, EAM and BSA designed the experiments and wrote the manuscript. MJK, DSK, MJP and BJA performed the experiments and analyzed the data. EAM and BSA confirmed the authenticity of all the raw data. EAM, EBJ and BSA analyzed the data and revised the manuscript. All authors have read and approved the final manuscript.

\section{Ethics approval and consent to participate}

Not applicable.

\section{Patient consent for publication}

Not applicable.

\section{Competing interests}

The authors declare that they have no competing interests.

\section{References}

1. Tayarani-Najaran Z, Akaberi M, Vatani M and Emami SA Evaluation of antioxidant and anti-melanogenic activities of different extracts from aerial parts of Nepeta binaludensis Jamzad in murine melanoma B16F10 cells. Iran J Basic Med Sci 19: 662-669, 2016

2. Slominski A, Tobin DJ, Shibahara S and Wortsman J: Melanin pigmentation in mammalian skin and its hormonal regulation. Physiol Rev 84: 1155-1228, 2004.

3. Slominski A, Zmijewski MA and Pawelek J: L-tyrosine and L-dihydroxyphenylalanine as hormone-like regulators of melanocyte functions. Pigment Cell Melanoma Res 25: 14-27, 2012.

4. Wang L, Oh JY, Kim YS, Lee HG, Lee JS and Jeon YJ: Anti-photoaging and anti-melanogenesis effects of fucoidan isolated from Hizikia fusiforme and its underlying mechanisms. Mar Drugs 18: 427, 2020.

5. Rok J, Otręba M, Buszman E and Wrześniok D: Melanin-from melanocyte to keratinocyte, that is how melanin is transported within the skin. Ann Acad Med Siles 66: 60-66, 2012.

6. Slominski A, Wortsman J, Luger T, Paus R and Solomon S: Corticotropin releasing hormone and proopiomelanocortin involvement in the cutaneous response to stress. Physiol Rev 80: 979-1020, 2000.

7. Slominski AT, Zmijewski MA, Skobowiat C, Zbytek B, Slominski RM and Steketee JD: Sensing the environment: Regulation of local and global homeostasis by the skin's neuroendocrine system. Adv Anat Embryol Cell Biol 212: v, vii, 1-115, 2012.

8. Otręba M, Buszman E, Miliński M and Wrześniok D: Hypomelanoses transmitted from generation to generation. Postepy Hig Med Dosw (Online) 68: 1081-1090, 2014 (In Polish).

9. Otręba M, Miliński M, Buszman E, Wrześniok D and Beberok A: Hereditary hypomelanocytoses: the role of PAX3, SOX10, MITF SNAI2, KIT, EDN3 and EDNRB genes. Postepy Hig Med Dosw (Online) 67: 1109-1118, 2013 (In Polish).
10. Goswami P and Sharma HK: Skin hyperpigmentation disorders and use of herbal extracts: A review. Curr Trends Pharm Res 7: 81-104, 2020.

11. Burger P, Landreau A, Azoulay S, Michel T and Fernandez X: Skin whitening cosmetics: Feedback and challenges in the development of natural skin lighteners. Cosmetics 3: 36, 2016.

12. Pollock S, Taylor S, Oyerinde O, Nurmohamed S, Dlova N, Sarkar R, Galadari H, Manela-Azulay M, Chung HS, Handog E and Kourosh AS: The dark side of skin lightening: An international collaboration and review of a public health issue affecting dermatology. Int J Womens Dermatol 7: 158-164, 2020.

13. Cestari TF, Dantas LP and Boza JC: Acquired hyperpigmentations. An Bras Dermatol 89: 11-25, 2014.

14. Blaut M, Braune A, Wunderlich S, Sauer P, Schneider H and Glatt H: Mutagenicity of arbutin in mammalian cells after activation by human intestinal bacteria. Food Chem Toxicol 44: 1940-1947, 2006.

15. Hwang KS, Yang JY, Lee JY, Lee YR, Kim SS, Kim GR, Chae JS, Ahn JH, Shin DS, Choi TY and Bae MA: A novel anti-melanogenic agent, KDZ-001, inhibits tyrosinase enzymatic activity. J Dermatol Sci 89: 165-171, 2018.

16. Saeedi M, Eslamifarb M and Khezri K: Kojic acid applications in cosmetic and pharmaceutical preparations. Biomed Pharmacother 110: 582-593, 2019.

17. Lee R, Ko HJ, Kim K, Sohn Y, Min SY, Kim JA, Na D and Yeon JH: Anti-melanogenic effects of extracellular vesicles derived from plant leaves and stems in mouse melanoma cells and human healthy skin. J Extracell Vesicles 9: 1703480, 2019.

18. Fong $\mathrm{P}$ and Tong HH: In silico prediction of the cosmetic whitening effects of naturally occurring lead compounds. Nat Prod Commun 7: 1287-1294, 2012.

19. Huang HC, Wang HF, Yih KH, Chang LZ and Chang TM: The dual antimelanogenic and antioxidant activities of the essential oil extracted from the leaves of acorus macrospadiceus (Yamamoto) F. N. Wei et Y.K. Li. Evid Based Complement Alternat Med 2012: 781280, 2012.

20. Huang HC, Ho YC, Lim JM, Chang TY, Ho CL and Chang TM: Investigation of the anti-melanogenic and antioxidant characteristics of eucalyptus camaldulensis flower essential oil and determination of its chemical composition. Int J Mol Sci 16: 10470-10490, 2015.

21. Wu M, Hemesath TJ, Takemoto CM, Horstmann MA, Wells AG, Price ER, Fisher DZ and Fisher DE: c-Kit triggers dual phosphorylations, which couple activation and degradation of the essential melanocyte factor Mi. Genes Dev 14: 301-12, 2000.

22. Herdwiani W, Soemardji AA, Elfahmi and Tan MI: Review of cinnamon as a potent anticancer drug. Asian J Pharma Clin Res 9: 8-13, 2016.

23. Kuo ZK, Lin MW, Lu IH, Yao HJ, Wu HC, Wang CC, Lin SH, Wu SY, Tong TS, Cheng YC, et al: Antiangiogenic and antihepatocellular carcinoma activities of the Juniperus chinensis extract. BMC Complement Altern Med 16: 277, 2016.

24. Chung KS, Cheon SY, Roh SS, Lee $M$ and An $\mathrm{HJ}$. Chemopreventive effect of Aster glehni on inflammation-induced colorectal carcinogenesis in mice. Nutrients 10: 202, 2018.

25. Kim J, Jung KH, Yan HH, Cheon MJ, Kang S, Jin X, Park S, Oh MS and Hong SS: Artemisia capillaris leaves inhibit cell proliferation and induce apoptosis in hepatocellular carcinoma. BMC Complement Altern Med 18: 147, 2018.

26. Kono R, Nomura S, Okuno Y, Kagiya T, Nakamura M, Utsunomiya $\mathrm{H}$ and Ueno M: Two Japanese pepper (Zanthoxylum piperitum) fruit-derived compounds attenuate IgE-mediated allergic response in vitro and in vivo via inhibition of mast cell degranulation. Eur J Pharmacol 885: 173435, 2020.

27. Kim SS, Baik JS, Oh TH, Yoon WJ, Lee NH and Hyun CG: Biological activities of Korean Citrus obovoides and Citrus natsudaidai essential oils against acne-inducing bacteria. Biosci Biotechnol Biochem 72: 2507-2513, 2008.

28. Kang GJ, Han SC, Yi EJ, Kang HK and Yoo ES: The inhibitory effect of premature Citrus unshiu extract on atopic dermatitis in vitro and in vivo. Toxicol Res 27: 173-180, 2011.

29. Choi SY, Ko HC, Ko SY, Hwang JH, Park JG, Kang SH, Han SH, Yun SH and Kim SJ: Correlation between flavonoid content and the NO production inhibitory activity of peel extracts from various citrus fruits. Biol Pharm Bull 30: 772-778, 2007.

30. Jin KS, Lee JY, Hyun SK, Kim BW and Kwon HJ: Juniperus chinensis and the functional compounds, cedrol and widdrol, ameliorate $\alpha$-melanocyte stimulating hormone-induced melanin formation in B16F10 Cells. Food Sci Biotechnol 24: 611-618, 2015. 
31. Jin S, Yun HJ, Jeong HY, Oh YN, Park HJ, Yun SG, Kim BW and Kwon HJ: Widdrol, a sesquiterpene isolated from Juniperus chinensis, inhibits angiogenesis by targeting vascular endothelial growth factor receptor 2 signaling. Oncol Rep 34: 1178-1184, 2015

32. Lee SW, Lim JM, Mohan H, Seralathan KK, Park YJ, Lee JH and Oh BT: Enhanced bioactivity of Zanthoxylum schinifolium fermented extract: Anti-inflammatory, anti-bacterial, and anti-melanogenic activity. J Biosci Bioeng 129: 638-645, 2020.

33. Laskin JD, Piccinini L, Engelhardt DL and Weinstein IB: Control of melanin synthesis and secretion by B16/C3 melanoma cells. J Cell Physiol 113: 481-486, 1982.

34. Bhatnagar V, Srirangam A and Abburi R: In vitro modulation of proliferation and melanization of melanoma cells by citrate. Mol Cell Biochem 187: 57-65, 1998.

35. Jeong $\mathrm{CH}$ and Shim $\mathrm{KH}$ : Tyrosinase inhibitor isolated from the leaves of Zanthoxylum piperitum. Biosci Biotechnol Biochem 68: 1984-1987, 2004.

36. Saba E, Oh MJ, Lee YY, Kwak D, Kim S and Rhee MH: Artemisia capillaris thunb. Inhibits melanin synthesis activity via ERK-dependent MITF pathway in B16/F10 melanoma cells. Korean J Vet Res 58: 1-7, 2018.

37. Kim JK, Park NH and Hwang JS: Skin lightening effect of the dietary intake of citrus peel extract against UV-induced pigmentation. Nat Prod Commun 14: 1934578X19859979, 2019.

38. Burt S: Essential oils: Their antibacterial properties and potential applications in foods-a review. Int J food Microbiol 94: 223-253, 2004.

39. Popa M, Măruțescu L, Oprea E, Bleotu C, Kamerzan C, Chifiriuc MC and Grădișteanu Pircalabioru G: In vitro evaluation of the antimicrobial and immunomodulatory activity of culinary herb essential oils as potential perioceutics. Antibiotics (Basel) 9: 428, 2020.
40. Dangkulwanich M and Charaslertrangsi T: Hydrodistillation and antimicrobial properties of lemongrass oil (Cymbopogon citratus, Stapf): An undergraduate laboratory exercise bridging chemistry and microbiology. J Food Sci Educ 19: 41-48, 2020.

41. Baldea I, Mocan T and Cosgarea R: The role of ultraviolet radiation and tyrosine stimulated melanogenesis in the induction of oxidative stress alterations in fair skin melanocytes. Exp Oncol 31: 200-208, 2009.

42. Kim ES, Park SJ, Goh MJ, Na YJ, Jo DS, Jo YK, Shin JH, Choi ES, Lee HK, Kim JY, et al: Mitochondrial dynamics regulate melanogenesis through proteasomal degradation of MITF via ROS-ERK activation. Pigment Cell Melanoma Res 27: 1051-1062, 2014

43. Hong JH, Lee JW, Park JH and Lee IS: Antioxidative and cytoprotective effects of Artemisia capillaris fractions. Biofactors 31: 43-53, 2007.

44. Kim ZH, Hwang JW, Lee JH, Kim H, Lim DS, Kang S, Lee HS and Choi YS: Whitening effect of storage protein 2 from silkworm hemolymph. Adv Biosci Biotechnol 5: 758-767, 2014.

45. Eberle J, Garbe C, Wang N and Orfanos CE: Incomplete expression of the tyrosinase gene family (tyrosinase, TRP-1, and TRP-2) in human malignant melanoma cells in vitro. Pigment Cell Res 8: 307-313, 1995 .

(i) This work is licensed under a Creative Commons

EY Attribution 4.0 International (CC BY 4.0) License. 